\title{
Pengaruh Promo Cashback Berbagai Jenis e-Payment Terhadap Loyalitas Konsumen (Studi Kasus : Chatime Indonesia)
}

\author{
Dewi Ayu Kusumaningrum ${ }^{1}$, Dandy Prasetia Setiawan ${ }^{2}$ \\ ${ }^{1}$ Politeknik Sahid; dewiayu@ @olteksahid.ac.id* \\ ${ }^{2}$ Politeknik Sahid; dandyssetiawan@gmail.com
}

Received 01 Februari 2021| Revised 05 Maret 2021 | Accepted 05 Maret 2021

*Korespondensi Penulis

\begin{abstract}
Abstrak
Perkembangan penjualan minuman bubble tea sangat drastis meningkat. Salah satu usaha minuman bubble tea yang digemari masyarakat Indonesia adalah Chatime. Chatime menjadi top brand minuman bubble teratas di Indonesia untuk tahun 2016 - 2019. Tingginya konsumsi produk Chatime tidak hanya dikarenakan kualitas produk yang baik tetapi juga didukung pemasaran yang berkembang seiring perkembangan teknologi dan komunikasi, khususnya financial technology yaitu platform E-Payment. Kemudahan pembayaran serta sering diberikannya promo membuat penggunaan E-Payment semakin meningkat. Berdasarkan data lembaga survey Nielsen tahun 2016, promo dalam bentuk cashback yang paling diminati konsumen dalam pembelian produk. Penelitian ini bertujuan untuk melihat pengaruh promo cashback berbagai jenis E-Payment terhadap loyalitas konsumen (studi kasus: Chatime Indonesia). Metode penelitian deskriptif dengan pendekatan kuantitatif. Penelitian dilakukan di beberapa outlet Chatime Indonesia di Jakarta. Target penelitian adalah konsumen Chatime Indonesia dengan teknik non probability sampling, metode multi stage sampling yaitu Insidental Sampling dan Purposive Sampling sebanyak 100 responden. Pengumpulan data dengan Instrument kuisoner. Analisis data dengan analisis statistika regresi menggunakan aplikasi software SPSS for windows 20. Hasil didapatkan hipotesis diterima dengan nilai signifikan sebesar $0,000<0,05$ dan t hitung $(17,893)>\mathrm{t}$ tabel $(1,99045)$ artinya ada pengaruh program promosi cashback terhadap loyalitas konsumen di Chatime. Loyalitas Konsumen dipengaruhi oleh promosi cashback sebesar 76,6\% sedangkan sisanya $23,4 \%$ dipengaruhi oleh faktor lain. Saran yang dapat disampaikan dapat melanjutkan penelitian terkait faktor lain yang memengaruhi loyalitas konsumen. Serta bagi pelaku bisnis lain dapat menggunakan alternative promo cashback sebagai pilihan promosi produk.
\end{abstract}

Kata Kunci: Promosi; E-Payment; Loyalitas, OVO; GOPAY; Shopeepay

\begin{abstract}
The development of bubble tea sales has increased drastically. One of the bubble tea beverage businesses favored by Indonesians is Chatime. Chatime is the top bubble drink brand in Indonesia for 2016 - 2019. The high consumption of Chatime products is not only due to good product quality but also supported by marketing that develops along with developments in technology and communication, especially financial technology, namely the E-Payment platform. Ease of payment and frequent promos make the use of E-Payment increasing. Based on data from the Nielsen survey institute in 2016, promos in the form of cashback are the most popular for consumers in purchasing products. This study aims to determine the effect of various types of E-Payment cashback promos on consumer loyalty (case study: Chatime Indonesia). Descriptive research method with a quantitative approach. The research was conducted at several Chatime Indonesia outlets in Jakarta. The research target is Chatime Indonesia consumers with non-probability sampling techniques, multi-stage sampling methods, namely incidental sampling and purposive sampling of 100 respondents. Data collection using questionnaire instrument. Data analysis with regression statistical analysis using the SPSS for windows 20 software application. The results obtained by the hypothesis are accepted with a significant value of $0.000<0.05$ and t count
\end{abstract}


(17.893) >t table (1.99045), meaning that there is an effect of promotion cashback on consumer loyalty in Chatime. Consumer Loyalty is influenced by cashback promotion of $76.6 \%$ while the remaining $23.4 \%$ is influenced by other factors. Suggestions that can be conveyed can continue research related to other factors that affect consumer loyalty. As well as for other business players, they can use an alternative cashback promo as a product promotion option.

Keywords: Promotion; E-Payment; Loyalty; OVO; GOPAY; Shopeepay

\section{PENDAHULUAN}

Industri usaha minuman di Indonesia Industri usaha minuman di Indonesia memiliki prospek yang positif. Hal ini didukung data Kementerian Perindustrian Indonesia yang menyatakan bahwa sektor makanan dan minuman menjadi sektor penyumbang Pendapatan Domestik Bruto (PDB) terbesar, sebesar 35,58\% terhadap PDB Industri Non Migas dan sebesar 6,35\% terhadap PDB Nasional (www.pikiran-rakyat.com, 2019). Jenis minuman yang saat ini sangat digemari adalah minuman bubble tea.

Perkembangan penjualan minuman bubble tea sangat drastis meningkat. Berdasarkan data Grab, yang memiliki pelayanan pembelian konsumsi secara online via GrabFood, didapatkan data kenaikan signifikan pertumbuhan penjualan minuman bubble tea pada tahun 2018. Berdasarkan data tersebut, terjadi pertumbuhan penjualan sekitar 3000\% di Asia Tenggara. Indonesia menempati peringkat pertama di antara negara-negara di Asia Tenggara dengan angka pertumbuhan penjualan lebih dari $8.500 \%$. Terdapat data rata-rata setiap orang meminum 4 gelas bubble tea per bulan melalui pemesanan via GrabFood (www.grab.com, 2019). Salah satu usaha minuman bubble tea yang digemari masyarakat Indonesia adalah Chatime.

Chatime merupakan usaha food \& beverages dengan produk unggulan milktea dengan sistem franchise yang berasal dari Taiwan sejak tahun 2003. Chatime merupakan franchise bertaraf internasional dengan lebih dari 2500 outlet di 38 negara termasuk Indonesia. Chatime merupakan tempat awal tercipta minuman tapioca pearl yang kemudian dikenal dengan bubble atau boba (www.creativeunicorn.com, 2019) Chatime menjadi top brand minuman bubble teratas di Indonesia untuk tahun 2016 - 2019 (www.topbrand-award.com, 2019). Berdasarkan data dapat dilihat chatime menjadi pilihan teratas konsumen dalam hal minuman bubble tea. Tingginya konsumsi produk Chatime tidak hanya dikarenakan kualitas produk yang baik tetapi juga didukung pemasaran yang baik. Pemasaran dari transaksi manual di outlet dan transaksi online. Pembelian produk melalui pemesanan online berkembang seiring perkembangan teknologi dan komunikasi, khususnya financial technology.

Jenis financial technology yaitu pembayaran untuk pemesanan online melalui platform $E$ Payment. Smartphone menjadi media yang digunakan untuk melalukan seluruh kegiatan tersebut. Terciptanya sistem transaksi ini menjadikan kegiatan pembayaran menjadi lebih praktis karena diketahui lebih aman, efektif, efisien, dan cepat. Kemudahan pembayaran serta sering diberikannya promo membuat penggunaan E-Payment semakin meningkat. Hal ini didukung data penelusuran untuk aplikasi e-money mengalami kenaikan 1,5 kali di tahun 2017 dari tahun-tahun sebelumnya (www.femina.co.id, 2019)

E-Payment menjadi metode pembayaran yang kini sedang populer di masyarakat, tersedianya berbagai macam E-Paymentseperti GO-PAY dari GO-JEK, OVO dari Lippo Group, Dana dari grup EMTEK, T-Cash dari Telkomsel, Shopee pay dari grup Shopee, dan sebagainya. Terdapat 38 E-Payment dengan lisensi resmi, GO-PAY dari GO-JEK sebagai dompet digital dengan pengguna aktif bulanan terbesar di Indonesia (www.databoks.katadata.co.id, 2019).

Layanan berbasis E-Payment mengundang banyak perusahaan untuk kerjasama, salah satunya Chatime. Chatime berupaya selain untuk mendapatkan keuntungan, juga ingin menciptakan loyalitas konsumen terhadap produk Chatime. Dengan layanan berbasis E-Payment memudahkan konsumen dalam bertransaksi sehingga diharapkan akan membeli produk, merekomendasikan serta memiliki komitmen pembelian ulang yang dimana kesemua hal tersebut disebut sebagai loyalitas konsumen (Yuliana, 2017). Loyalitas dapat terwujud dengan langkah awal meyakini konsumen dengan produk dan pendukungnya, salahsatunya kemudahan transaksi dengan E-Payment 
Layanan berbasis E-Payment sering memberikan promo seperti diskon harga, cashback, pemberian benefit pada rewards point. Bagi kebanyakan konsumen Indonesia, kata promo atau diskon memang masih menjadi magnet yang memengaruhi keputusan untuk membeli. Hal ini didukung data pencarian kata 'Promo' di Google Search mengalami kenaikan hingga 2,5 kali di tahun 2018 dibanding tahun-tahun sebelumnya (www.femina.co.id, 2019). Hal ini menandakan konsumen sangat menantikan promo dalam membeli produk. Terutama jenis promo cashback yang banyak menyita perhatian konsumen.

Berdasarkan data lembaga survey Nielsen tahun 2016, promo dalam bentuk cashback yang paling diminati konsumen dalam pembelian produk didukung pula data survei Shopback menunjukkan sebesar $51,6 \%$ responden Indonesia mengaku menggunakan aplikasi E-Payment saat ada promo cashback berlangsung karena paling disukai dan dipercaya (ekonomi.bisnis.com, 2018). Dengan promo cashback yang ditawarkan diharapkan tidak hanya dapat menarik konsumen, tapi juga diharapkan dapat menciptakan loyalitas pada konsumen. Hal ini menarik peneliti untuk melakukan penelitian terkait promo khususnya cashback dari berbagai jenis E-Payment dikaitkan dengan loyalitas konsumen.

Dalam 10 tahun terakhir, hanya sedikit penelitian sebelumnya terkait khusus tema cashback dan loyalitas konsumen. Antara lain didapatkan hasil promo cashback berhubungan signifikan namun rendah dengan loyalitas pelanggan muslim Surabaya (Amelia \& Fikriyah, 2020). Penelitian lain yaitu menunjukkan hasil terdapat pengaruh yang kuat dan positif antara Promosi Cashback terhadap Kepuasan Pelanggan memiliki pengaruh pembentukan Loyalitas pelanggan Digital wallet khusus Gopay dan OVO (Pratama, 2019). Sedangkan untuk secara umum penelitian lain sebelumnya mengaitkan cashback dengan minat beli atau mengaitkan loyalitas dengan bauran pemasaran umum, atau hanya meneliti satu jenis E-Payment.

Oleh karena itu, penelitian ini bertujuan untuk melihat pengaruh promo cashback berbagai jenis E-Payment terhadap loyalitas konsumen (studi kasus : Chatime Indonesia).

\section{Promosi}

Promosi adalah usaha yang dilakukan penjual dengan menggunakan berbagai media informasi untuk menarik konsumen (Morissan, 2015). Media informasi yang digunakan dapat berupa media offline dan online, seperti media cetak, televisi, media internet. Tujuan promosi adalah menarik perhatian dan mempengaruhi keputusan pembelian terhadap suatu barang dan jasa. Untuk mancapai tujuan promosi, dibutuhkan elemen promosi atau yang disebut bauran promosi (promotional mix).

Bauran promosi atau promotional mix sangat penting dalam komunikasi pemasaran yang terdiri dari enam poin yaitu iklan (advertising), promosi penjualan (sales promotion), publikasi / humas, personal selling, direct marketing dan interactive media (Morissan, 2015). Yang kemudian ini dilengkapi dengan teori Kotler dan Keller, komunikasi pemasaran berperan penting dalam penjualan serta membangun ekuitas merek yang terdiri dari delapan poin yaitu (Kotler \& Keller, 2016);

1. Advertising / Iklan,

Iklan merupakan bagian dari kegiatan promosi barang dan jasa. Berbagai jenis media iklan dapat berupa media offline (media cetak) seperti koran, pamphlet, brosur, leaflet, spanduk, baligho atau media online (media elektronik) seperti televisi, radio, dan internet.

2. Sales promotion/Promosi penjualan

Kegiatan sales promotion melibatkan persuasi langsung kepada konsumen untuk membuat konsumen membeli produk atau jasa yang ditawarkan. Kegiatan ini dapat dilakukan dengan menawarkan untuk mencoba produk baru, memberikan barang gratis, kupon, rabat diskon, premi, kontes, trading stamp, demontrasi, bonus, hadiah uang, perlombaan, dan lain-lain.

3. Events sponsorship

Event Sponsorship adalah kegiatan yang bertujuan meningkatkan pengenalan produk dan perusahaan kepada konsumen. Meningkatkan image positif terhadap perusahaan. Kegiatan yang dilakukan seperti mensponsori acara olahraga, kesenian, hiburan, dan sebagainya.

\section{Public relations}

Public relations menjalin komunikasi antara organisasi dan pihak luar organisasi agar konsumen memiliki image yang baik terhadap perusahaan. Kegiatan yang dilakukan seperti konferensi melalui media massa, dan customer service.

\section{Social media marketing}


Semua kegiatan promosi melalui media online khususnya social media seperti Facebook, Instagram yang bertujuan untuk meningkatkan kesadaran, meningkatkan citra, atau menimbulkan penjualan produk dan jasa.

6. Mobile marketing

Semua kegiatan promosi melalui media online dengan mempergunakan ponsel, smartphone, atau tablet konsumen.

7. Direct and database marketing

Semua kegiatan promosi melalui surat, telepon, fax, e-mail, atau internet untuk berkomunikasi secara langsung dengan atau meminta respon atau dialog dengan konsumen.

8. Personal selling

Personal selling adalah kegiatan bertemu langsung calon pembeli atau lebih dengan presentasi, menjawab pertanyaan, dan menerima pesanan. Dapat dikatakan kegiatan yang paling efektif dalam membangun preferansi, keyakinan, dan tindakan pembeli.

\section{Cashback}

Cashback merupakan jenis promo yang sering ditawarkan pelaku bisnis dengan ketentuan setelah konsumen membeli produk dapat memperoleh pengembalian uang tunai maupun uang virtual dengan persentase tertentu dengan syarat dan ketentuan yang berlaku (www.sodexo.co.id, 2020). Cashback memiliki keuntungan antara lain menarik konsumen baru, meningkatkan pembelian berulang sehingga meningkatkan transaksi, menjaga harga produk serta dapat meningkatkan brand awareness (gobiz.co.id, 2019).

\section{Loyalitas Konsumen}

Loyalitas pelanggan hal penting yang diperlukan usaha dalam mempertahankan kelancaran bisnis kedepannya. Loyalitas konsumen adalah sikap dan perilaku konsumen yang melakukan pembelian produk atau jasa secara konsisten dalam jangka waktu panjang (Marlius, 2017). Kotler dan Keller mengungkapkan loyalitas konsumen memiliki karakteristik sebagai berikut (Kotler \& Keller, 2016):

1. Satisfaction (Kepuasan)

Kepuasan meliputi terpenuhinya keinginan serta harapan. Keinginan yag terbentuk dari kebutuhan konsumen dan pengharapan terpenuhi dari pembelian dan penggunaan produk atau jasa yang ditawarkan.

2. Repeat purchase (Pembelian ulang)

Pembelian ulang adalah perilaku konsumsi produk/jasa secara berkali-kali.

3. Word of Mouth/Buzz (Komunikasi mulut ke mulut)

Words Of Mouth hal penting dalam menarik konsumen baru melalui konsumen yang telah mencoba lebih dulu dan memberikan referensi atau testimonial.

4. Evangelism (Meyakinkan)

Kegiatan yang meyakinkan produk atau layanan jasa kepada calon konsumen baru. Hal ini menguntungkan produsen karena seperti memiliki agen promosi gratis.

5. Ownership (Kepemilikan)

Elemen terakhir loyalitas adalah perasaan memiliki tanggung jawab atas keberlangsungan bisnis perusahaan yang berkesinambungan.

\section{Kerangka Penelitian}

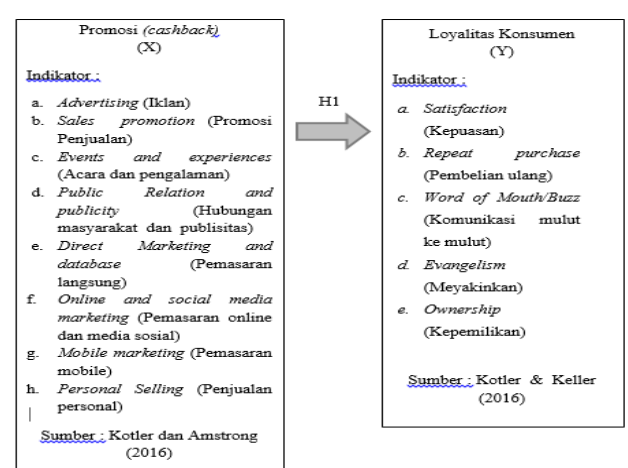

Gambar 1. Kerangka Penelitian 
Berdasarkan kerangka pikir di atas, maka penulis membuat hipotesis sebagai berikut:

H0 : Promo cashback berbagai jenis E-Payment tidak memiliki pengaruh terhadap loyalitas konsumen H1: Promo cashback berbagai jenis E-Payment memiliki pengaruh terhadap loyalitas konsumen

\section{METODE}

Penelitian ini merupakan penelitian deskriptif dengan pendekatan kuantitatif. Waktu penelitian berlangsung selama 3 bulan tahun 2020 dengan kendala keadaan pandemic Covid-19 yang menyulitkan peneliti bertemu langsung dengan responden. Penelitian dilakukan di beberapa outlet Chatime Indonesia di Jakarta. Target penelitian dalam penelitian ini adalah konsumen Chatime Indonesia. Peneliti menggunakan teknik non probability sampling sebagai metode untuk mencari sampel untuk penelitian ini dan juga metode multi stage sampling. Responden yang diambil tidak semua populasi sehingga ditentukan pemutusan ukuran sampel sebanyak 100 responden. Prosedur pengumpulan data dilakukan dengan melakukan wawancara langsung kepada responden yang telah memenuhi persyaratan menggunakan instrumen kuesioner berupa pernyataan yang bersifat tertutup. Pernyataan dinilai dengan skala likert skala 1-5, dan skala nilainya sangat tidak setuju sampai sangat setuju. Teknik analisis data dengan analisis statistika, yaitu meliputi uji validitas, reliabilitas, normalitas dan heteroskedastisitas dan dilanjutkan dengan uji hipotesis pengaruh variabel bebas (independen variabel) terhadap variabel terikat (dependent variable).

\section{HASIL DAN PEMBAHASAN}

\section{Uji Validitas}

Tabel 1. Uji Validitas Variabel X

\begin{tabular}{lcc}
\hline Pernyataan & r hitung & r tabel \\
\hline Pernyataan 1 & 0,665 & 0,1966 \\
Pernyataan 2 & 0,716 & 0,1966 \\
Pernyataan 3 & 0,852 & 0,1966 \\
Pernyataan 4 & 0,689 & 0,1966 \\
Pernyataan 5 & 0,819 & 0,1966 \\
Pernyataan 6 & 0,595 & 0,1966 \\
Pernyataan 7 & 0,663 & 0,1966 \\
Pernyataan 8 & 0,708 & 0,1966 \\
Pernyataan 9 & 0,694 & 0,1966 \\
Pernyataan 10 & 0,771 & 0,1966 \\
Pernyataan 11 & 0,830 & 0,1966 \\
Pernyataan 12 & 0,739 & 0,1966 \\
Pernyataan 13 & 0,783 & 0,1966 \\
Pernyataan 14 & 0,823 & 0,1966 \\
Pernyataan 15 & 0,788 & 0,1966 \\
Pernyataan 16 & 0,781 & 0,1966 \\
Pernyataan 17 & 0,736 & 0,1966 \\
Pernyataan 18 & 0,838 & 0,1966 \\
Pernyataan 19 & 0,770 & 0,1966 \\
Pernyataan 20 & 0,679 & 0,1966 \\
\hline Sumber : Olahan data peneliti, 2020
\end{tabular}

Berdasarkan tabel di atas, dapat dilihat sebanyak 20 pernyataan variable $\mathrm{X}$ memiliki nilai $\mathrm{r}$ hitung lebih dari $\mathrm{r}$ tabel, maka 20 pernyataan variable $\mathrm{X}$ adalah Valid. 
Tabel 2. Uji Validitas Variabel Y

\begin{tabular}{ccc}
\hline Pernyataan & r hitung & r tabel \\
\hline Pernyataan 1 & 0,640 & 0,1966 \\
Pernyataan 2 & 0,665 & 0,1966 \\
Pernyataan 3 & 0,827 & 0,1966 \\
Pernyataan 4 & 0,880 & 0,1966 \\
Pernyataan 5 & 0,829 & 0,1966 \\
Pernyataan 6 & 0,801 & 0,1966 \\
Pernyataan 7 & 0,839 & 0,1966 \\
Pernyataan 8 & 0,885 & 0,1966 \\
Pernyataan 9 & 0,863 & 0,1966 \\
Pernyataan 10 & 0,887 & 0,1966 \\
Pernyataan 11 & 0,922 & 0,1966 \\
Pernyataan 12 & 0,884 & 0,1966 \\
Pernyataan 13 & 0,849 & 0,1966 \\
Pernyataan 14 & 0,808 & 0,1966 \\
Pernyataan 15 & 0,748 & 0,1966 \\
\hline Sumber : Olahan data peneliti, 2020
\end{tabular}

Berdasarkan tabel di atas, dapat dilihat sebanyak 15 pernyataan variable $Y$ memiliki nilai $r$ hitung lebih dari $\mathrm{r}$ tabel, maka 20 pernyataan variable $\mathrm{Y}$ adalah Valid.

\section{Uji Reliabilitas}

Tabel 3. Uji Reliabilitas

\begin{tabular}{ccc}
\hline Variabel & $\begin{array}{c}\text { Cronbach } \\
\text { Alpha }\end{array}$ & Standar \\
\hline $\mathrm{X}$ & 0,957 & 0,600 \\
$\mathrm{Y}$ & 0,965 & 0,600 \\
\hline \multicolumn{3}{l}{ Sumber : Olahan data peneliti, 2020}
\end{tabular}

Berdasarkan tabel di atas, dapat dilihat variable X dan variable Y memiliki nilai Cronbach Alpha lebih dari nilai standar, maka kedua variabel adalah Reliabel.

\section{Uji Normalitas}

Tabel 4. Uji Normalitas

One Sample Kolmogorov-Smirnov Test

\begin{tabular}{cc}
\hline Asymp Sig. 2 tailed & Standar \\
\hline 0,200 & 0,05 \\
\hline Sumber : Olahan data peneliti, 2020
\end{tabular}

Berdasarkan tabel di atas, dapat dilihat memiliki nilai Asymp Sig. 2 tailed lebih dari nilai standar, maka Normal.

\section{Uji Heteroskedastisitas}

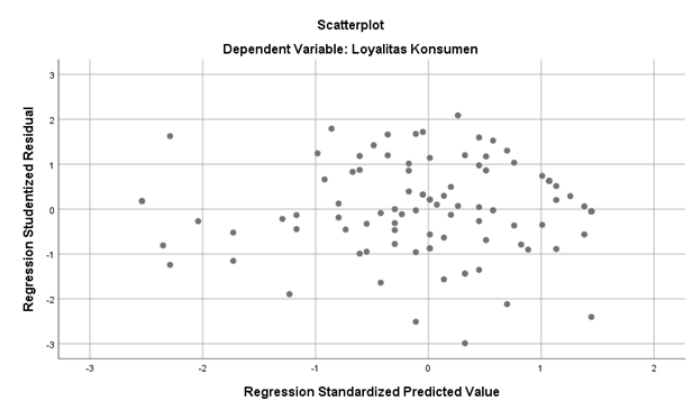

Gambar 2. Grafik Scatterplots

Sumber : Olahan data peneliti, 2020 
Berdasarkan gambar di atas tidak terdapat pola tertentu dari titik-titik yang dihasilkan, maka tidak terjadi heterokedastisitas.

\section{Uji Regresi Linier Sederhana}

Tabel 5. Uji Regresi Linier Sederhana

\begin{tabular}{cc}
\hline Model & Coefficients \\
\hline (Constant) & 2,773 \\
Promosi & 0,726 \\
\hline
\end{tabular}

Dari tabel dapat dituliskan persamaan regresi sebagai berikut: $Y=2,773+0,726 X$. Nilai konstanta dari koefisien regresi sebesar 2,773, hal ini menyatakan bahwa jika tidak ada kenaikan nilai atau skor dari variabel promosi cashback, maka variabel loyalitas konsumen adalah 2,773. Koefisien regresi sebesar 0,726 menyatakan bahwa setiap terjadi penambahan skor variabel promosi cashback dapat menambah kenaikan variabel Loyalitas Konsumen.

\section{Uji Determinasi (R Square)}

Tabel 6. Uji Determinasi (R Square)

\begin{tabular}{ccc}
\hline Model & R & R Square \\
\hline 1 & 0,875 & 0,766 \\
\hline \multicolumn{3}{c}{ Sumber : Olahan data peneliti, 2020}
\end{tabular}

Diperoleh data analisis korelasi determinasi nilai $\mathrm{R}$ menghasilkan nilai korelasi antara Promosi dengan Loyalitas Konsumen sebesar 0,875. Nilai $\mathrm{R}$ Square merupakan nilai determinasi (kuadrat dari koefisien korelasi 0,875 ) sebesar 0,766 . R Square disebut koefisien determinan yang dalam hal ini 76,6\%. Dari nilai tersebut dapat diartikan bahwa 76,6\% Loyalitas Konsumen dipengaruhi oleh promosi cashback sedangkan sisanya $23,4 \%$ dipengaruhi oleh faktor lain.

\section{Uji Hipotesis (Uji t)}

\begin{tabular}{ccc}
\multicolumn{3}{c}{ Tabel 7. Uji t } \\
\hline Model & $\mathbf{t}$ & Sig. \\
\hline (Constant) & 0,872 & 0,385 \\
Promosi & 17,893 & 0,000 \\
\hline
\end{tabular}

Sumber : Olahan data peneliti, 2020

Nilai $\mathrm{t}$ tabel didapatkan dengan memperhatikan $\alpha=0,05$ dan $\mathrm{df}=\mathrm{n}-\mathrm{k}-1$ atau $\mathrm{df}=100-20-1=$ 79, maka didapatkan $\mathrm{t}$ tabel $=1,99045$. Pada tabel di atas $\mathrm{t}$ hitung sebesar 17,893 serta signifikansi 0,000 . Maka dapat disimpulkan bahwa nilai signifikan sebesar 0,000 lebih kecil dari 0,05 dan thitung $(17,893)$ lebih besar dari t tabel $(1,99045)$ maka Ho ditolak dan $\mathrm{H} 1$ diterima, artinya ada pengaruh program promosi cashback terhadap loyalitas konsumen di Chatime.

\section{Pembahasan}

Berdasarkan hasil data yang ditampilkan dapat diasumsikan konsumen Chatime yang menggunakan promo e-payment didominasi mahasiswa yang merupakan golongan masyarakat yang sangat mengikuti tren mengkonsumsi minuman bubble tea saat ini. Chatime merupakan pilihan brand teratas konsumen dalam hal minuman bubble tea. Brand yang terpercaya akan produk yang ditawarkan didukung dengan fasilitas financial technology yaitu pembayaran untuk pemesanan online melalui platform E-Payment yang menawarkan banyak promo antara lain promo cashback.

Hal ini dapat dilihat pada hasil data nilai koefisien regresi sebesar 0,726 menyatakan bahwa setiap terjadi penambahan skor 0,726 kali variabel promosi cashback dapat menambah kenaikan variabel Loyalitas Konsumen. Dapat diasumsikan bahwa dengan layanan berbasis E-Payment tidak hanya memudahkan konsumen dalam bertransaksi tapi dengan adanya E-Payment yang sering memberikan promo cashback memang memengaruhi keputusan konsumen untuk membeli, merekomendasikan serta 
berkomitmen melakukan pembelian ulang. Hal ini didukung hasil data Nilai R Square merupakan nilai determinasi sebesar 76,6\%, dengan artian Loyalitas Konsumen dipengaruhi oleh promosi cashback sebesar 76,6\% sedangkan sisanya 23,4\% dipengaruhi oleh 146actor lain. Serta hasil data nilai signifikan t hitung $(17,893)$ lebih besar dari t tabel $(1,99045)$ yang hipotesis penelitian diterima, yaitu Promo cashback berbagai jenis E-Payment memiliki pengaruh terhadap loyalitas konsumen di Chatime. Sesuai dengan artikel yang mengemukakan Cashback memiliki keuntungan yaitu menarik konsumen baru, meningkatkan pembelian berulang sehingga meningkatkan transaksi, menjaga harga produk serta dapat meningkatkan brand awareness (gobiz.co.id, 2019).

Promo cashback yang ditawarkan berbagai platform E-Payment yang bekerjasama dengan Chatime pada saat penelitian ini yaitu Gopay, OVO, Cashback, Link Aja dan ShopeePay. Promo cashback ini merupakan salahsatu kegiatan sales promotion yang menjangkau konsumen secara langsung dengan menawarkan promo. Promo Cashback pada berbagai platform E-Payment yang bekerjasama dengan Chatime secara terbukti dapat memberikan kepuasan konsumen dan membuat konsumen melakukan pembelian ulang adalah perilaku konsumsi produk, yang diikuti dengan perilaku konsumen memberikan referensi dan meyakinkan produk kepada calon konsumen baru, serta merasa menjaga keberlangsungan bisnis Chatime terus berlangsung.

\section{SIMPULAN}

\section{Kesimpulan}

Kesimpulan dari penelitian yang bertujuan untuk melihat pengaruh promo cashback berbagai jenis E-Payment terhadap loyalitas konsumen Chatime Indonesia adalah promo cashback berbagai jenis E-Payment memiliki pengaruh terhadap loyalitas konsumen di Chatime Indonesia. Konsumen Chatime yang menggunakan promo e-payment didominasi mahasiswa. Dimana Chatime merupakan Brand teratas untuk produk minuman bubble tea yang tidak hanya menawarkan produk terbaik tetapi juga didukung dengan fasilitas E-Payment yang menawarkan banyak promo antara lain promo cashback. Loyalitas konsumen menjadi hal yang sangat dibutuhkan bagi keberlangsungan bisnis. Promo cashback dapat dijadikan alternative pilihan promosi bagi bisnis lain dalam kegiatan pemasaran.

\section{Saran}

Berdasarkan hasil data yang didapatkan loyalitas konsumen dipengaruhi oleh promosi cashback sebesar 76,6\% sedangkan sisanya 23,4\% dipengaruhi oleh faktor lain. Maka saran yang dapat disampaikan bagi peneliti selanjutanya dapat melanjutkan penelitian terkait faktor lain yang memengaruhi loyalitas konsumen. Serta bagi pelaku bisnis lain dapat menggunakan alternative promo cashback sebagai pilihan promosi produk.

\section{DAFTAR PUSTAKA}

Amelia, F., \& Fikriyah, K. (2020). Hubungan Promo Cashback Terhadap Loyalitas Pelanggan Muslim Surabaya Dalam Pelayanan Digital Wallet OVO. Jurnal Ekonomika Dan Bisnis Islam , 108-115.

Ekonomi.Bisnis.Com. (2018, Oktober 8). "Cashback" Tarik Minat Masyarakat Berbelanja Daring. Retrieved From Ekonomi.Bisnis.Com: Ekonomi.Bisnis.Com

Firmansyah, A. (2017). Komunikasi Pemasaran. Pasuruan: Qiara Media.

Gobiz.Co.Id. (2019, September 26). 5 Keuntungan Promo Cashback Untuk Penjualan. Retrieved From Gobiz.Co.Id: Https://Gobiz.Co.Id/Pusat-Pengetahuan/Keuntungan-Promo-Cashback/

Kotler, P., \& Keller, K. L. (2016). Marketing Management, 15tb Edition,. Harlow, Essex, United Kingdom: Pearson Education Limited.

Kusumaningrum, D. A., \& Wachyuni, S. S. (2020). Promo Cashback Gopay Terhadap Minat Beli Bubble Drink (Studi Kasus : Yu Cha Indonesia, Pluit). Journal Of Tourism And Economic, 2330 .

Marlius, D. (2017). Loyalitas Nasabah Bank Nagari Syariah Cabang Bukittinggidilihat Darikualitas Pelayanan. Jurnal Pundi, Vol. 01, No. 03, November 2017, 237-250.

Morissan. (2015). Periklanan (Komunikasi Pemasaran Terpadu). Jakarta: Prenadamedia Group. 
Pratama, A. R. (2019). Pengaruh Promosi Cashback Terhadap Loyalitas Pelanggan Dengan Mediasi Kepuasan Pelanggan Dalam Pelayanan Digital Wallet Studi Kasus Gopay Dan Ovo. Jakarta: Universitas Bakrie.

Www.Creativeunicorn.Com. (2019). About Chatime. Retrieved From Www.Creativeunicorn.Com: Http://Www.Creativeunicorn.Com/Chatime/Staging/About.Html

Www.Databoks.Katadata.Co.Id. (2019, Agustus 12). Inilah Daftar Dompet Digital Terbesar Di Indonesia. Retrieved From Databoks.Katadata.Co.Id: Https://Databoks.Katadata.Co.Id/ Datapublish/2019/08/23/Inilah-Daftar-Dompet-Digital-Terbesar-Di-Indonesia

Www.Femina.Co.Id. (2019, Januari 3). Fenomena Cashback, Solusi Atau Konsumtif? Retrieved From Www.Femina.Co.Id: Https://Www.Femina.Co.Id/Money/Fenomena-Cashback-Solusi-AtauKonsumtif-

Www.Grab.Com. (2019, April 30). Demam Bubble Tea Di Grabfood! Retrieved From Https://Www.Grab.Com/Id/Press/Tech-Product/Demam-Bubble-Tea-Di-Grabfood/: Https://Www.Grab.Com/Id/Press/Tech-Product/Demam-Bubble-Tea-Di-Grabfood/

Www.Pikiran-Rakyat.Com. (2019, Agustus 1). Pertumbuhan Industri Makanan Dan Minuman Sumbang 6,35\% Terhadap Pdb Nasional. Retrieved From Www.Pikiran-Rakyat.Com: Https://Www.Pikiran-Rakyat.Com/Ekonomi/Pr-01316389/Pertumbuhan-Industri-MakananDan-Minuman-Sumbang-635-Terhadap-Pdb-Nasional?Page=2

Www.Sodexo.Co.Id. (2020, Februari 24). 5 Contoh Promosi Menarik Yang Bisa Diterapkan Untuk Bisnis Anda. Retrieved From Www.Sodexo.Co.Id: Https://Www.Sodexo.Co.Id/Contoh-PromosiMenarik/

Www.Topbrand-Award.Com. (2019). Bubble Drink | Top Brand Award. Retrieved From Www.Topbrand-Award.Com : Https://Www.Topbrand-Award.Com/En/2019/05/Bubble-Drink/

Yuliana, Y. (2017). Upaya Membangun Loyalitas Konsumen Melalui Pendekatan Kualitatif Pada Kualitas Produk Dan Kualitas Pelayanan Di Fakultas Ekonomi Umn Al Washliyah Medan T.A 2013/2014. Jurnal Penelitian Pendidikan Sosial Humaniora Vol. 2. No. 2 2017, 291-325.

Zainuddin, \& Cahya, N. (2019). Pengaruh Promo Penjualan Dan Cashback Terhadap Minat Beli Kendaraan Pada Pt. Hadji Kalla Palopo. Journal Of Institution And Sharia Finance, 1-19. 